\title{
THE PREDICTIVE VALUE OF THE CLINICAL SIGN OF EXCESSIVE HIP ABDUCTION FOR DEVELOPMENTAL DYSPLASIA OF THE HIP (DDH)
}

(C) by Acta Medica Saliniana ISSN 0350-364X

Type of manuscript: Professional papers

Title:

THE PREDICTIVE VALUE OF THE CLINICAL SIGN OF EXCESSIVE HIP ABDUCTION FOR DEVELOPMENTAL DYSPLASIA OF THE HIP (DDH)

Authors:

Svemir Čustović ${ }^{1,2}$, Kenan Čustović $^{3}$

DOI: $10.5457 / 479$

\section{Afiliations:}

${ }^{1}$ Clinic for Orthopedics and Traumatology, University Clinical Centre Tuzla, ${ }^{2}$ Department of Orthopedics, Medical Faculty, University of Tuzla, ${ }^{3}$ Medical Faculty, University of Tuzla, 75000 Tuzla Bosnia and Herzegovina.

Received: 12.10.2018.

\section{Corresponding author:}

Clinic for Orthopedics and

Traumatology, University Clinical

Centre Tuzla

Trnovac bb, 75000 Tuzla,

Bosnia and Herzegovina

Phone: +387 35303 246;

fax: +38735303270;

E-mail: svemir.custovic@bih.net.ba ORCID ID: https://orcid.org/00000002-0434-0390

Aim: To assess the relationship between the clinical sign of excessive hip abduction (abduction of the hip 90 degrees or more) and developmental dysplasia of the hip (DDH).

Methods: The research was conducted in 450 newborns in the Neonatal Unit at the Clinic of Gynecology and Obstetrics and the Clinic of Orthopedics and Traumatology of the University Clinical Centre, Tuzla, between 30th August 2011 and 30th April 2012. Clinical (degree of hip abduction) and ultrasound examination of hips in all newborns were performed using the Graf method on their first day of life.

Results: Clinical sign of excessive hip abduction showed significant predictive value for DDH. There were 37 (8.2\%) newborns with the clinical sign of excessive hip abduction: 13 had DDH, while 24 did not have this clinical sign. In overall sample, there were 89 newborns with one of the forms of DDH. 13 (12.7\%) had this clinical sign; while 24 (6.9\%) of 324 newborns without DDH had this clinical sign. Excessive hip abduction had a positive predictive value (PPV) of $35.1 \%$ and a negative predictive value (NPV) of $78.5 \%$ for DDH.

Conclusion: Excessive hip abduction is a useful and important clinical sign of DDH. Doctors who perform the first examination of the child after birth would have to turn their attention to this clinical sign. The newborns with this clinical sign would have to go to an ultrasound examination of the hips for further diagnosis.

Key words: predictive value, excessive hip abduction, developmental dysplasia of the hip (DDH).

\section{INTRODUCTION}

Developmental dysplasia of the hip is a challenging condition that represents a state of deformity and slow development of the hip joint in early childhood $(1,2)$. The term "developmental dysplasia of the hip" (DDH) describes a whole range of deformities involving the growing hip, including frank dislocation, subluxation and instability, and dysplasia of the femoral head and acetabulum. This term replaced the previously accepted "congenital dysplasia of the hip", which did not describe the developmental aspect of the disorder (3-5).

This deformity of the hip joint can be observed as a progressive illness where secondary structural changes will emerge in and around the joint tissue if a normal relation between the joint bodies is not established (6). Early diagnosis and treatment of DDH is critical, to provide the best possible functional outcome (7).

Developmental dysplasia of the hip is the most common deformity of the bone-joint system. The incidence of this deformity is different in different countries, according to the data given by various authors, varying from two to 50 or even more per 1,000 births $(3,7-10)$. This type of hip dysplasia occurs six times more frequently in girls. This defect can be diagnosed in over $40 \%$ of all cases and it occurs more often on the left than on the right hip.

The cause of development dysplasia is still not determined. Developmental dysplasia of the hip represents a dynamical process which arises as a result of a series of exogenous and endogenous factors, both physiological and mechanical, which have the same effect on the mother and child during pregnancy and after birth (11). It is considered multifactorial etiology in the occurrence of developmental dysplasia of the hip (12).

Developmental dysplasia of the hip (DDH) is a common and preventable cause of childhood disability and forms a large portion of pediatric orthopedic practice. It is generally agreed that a late diagnosis (often quoted as a diagnosis after three months) leads to a higher chance of requiring surgery and a higher risk of longterm complications (13). The criteria for 
defining cases of developmental dysplasia of the hip diagnosed later in life are uneven. If DDH is recognized early, treatment is less invasive, and long-term effects are minimized $(7,14)$.

The aim of this work was to assess the relation between excessive hip abduction and developmental dysplasia of the hip (DDH). Bosnia and Herzegovina does not have an accepted screening program for DDH. This study would help doctors, who clinically examine newborns for the first time, to make selection of children with DDH who will later be directed to further diagnostics.

\section{PATIENTS AND METHODS}

\section{Study design and patients}

The research was conducted in 450 newborns in the Neonatal Unit at the Clinic of Gynecology and Obstetrics and the Clinic of Orthopedics and Traumatology of the University Clinical Centre Tuzla, Bosnia and Herzegovina, from 30th August 2011 to 30th April 2012. During this period, 2678 babies were born. The survey included the newborns born at 37 to 42 weeks of gestation. A clinical and ultrasound hip examination was conducted on all newborns on the day of birth. The examination was done on the predetermined three days of the week.

\section{Methods}

The diagnosis of developmental dysplasia of the hip was determined in the Neonatal Unit by clinical and ultrasound hip examination. Through the clinical examination, possible excessive hip abduction was recorded.

The clinical examination starts from the child's socalled initial position. The child lies on the back, facing towards the doctor, with the hips in 90 degrees flexion, so that both thighs are held vertically, parallel to each other. This diagnostic procedure, which allows us to determine the stability of the hip joint, includes an assessment of the extent of hip abduction. Hip abduction is determined from the initial position where the thighs are spread simultaneously, without changing the initial flexion in the hips. Abduction is considered excessive if it is 90 degrees or more.
Ultrasound examinations were performed using a TOSHIBA SSA-240A (Kobe, Japan) apparatus with a $5 \mathrm{MHz}$ linear probe. Graf's ultrasound method was used (15). The hips were sorted according to Graf's type classification: a normal hip was classified as type I (Ia, Ib), a dysplastic hip as type II (IIa+, IIa-, IIb, IIc/g/d), a subluxed hip as type III (IIIa, IIIb) and a luxated hip as type IV (15).

\section{Statistical analysis}

All variables were tested for normal distribution using the Kolmogorov-Smirnov test and presented with baseline characteristics. Student's t-test was used for comparison of arithmetic means with the application of the paired sample t-test where appropriate. The $\chi 2$ test was used to compare frequencies between groups, with McNemar's test used for paired samples. The diagnostic accuracy was calculated using the usual measures of sensitivity, specificity and positive and negative predictive values, using a $2 \times 2$ table and Bayesian analysis. Univariate logistic regression was used to evaluate the predictive value of each variable of interest, by calculation of the odds ratio. All tests were performed with a statistical confidence level of $95 \%(\mathrm{p}<0.05)$.

\section{RESULTS}

The overall sample included 450 examinees, 205 (45.6\%) males and 245 (54.4\%) females. A total of 450 examinees (900 hips) underwent an ultrasound examination at birth. A total of $780(86.6 \%)$ hips had a normal ultrasound report, while 120 (13.4\%) were found to fall into one of the DDH categories. The prevalence of DDH was $13.4 \%$.

The sonographic report showed that type Ia was found in 507 (56.3\%) hips, transient form type Ib was found in $273(30.3 \%)$ and immature type IIa+ was found in $92(10.2 \%)$ hips. There were $22(2.4 \%)$ hips with an unstable-critical IIg sonographic report. There were four $(0.4 \%)$ decentred hips of type IID and $2(0.2 \%)$ decentred hips of type IIIa. None $(0 \%)$ of the hips was found to be sonographic type IV (luxated). There was no statistically significant difference in the appearance of developmental dysplasia of the hip between the right and left sides $(\mathrm{p}=0.48)$ (Table 1$)$.

Table 1. Distribution of sonographic in the hips of newborns in the overall sample during the first examination

\begin{tabular}{|l|c|c|c|}
\hline & \multicolumn{3}{|c|}{ No (\%) of newborns } \\
\hline $\begin{array}{l}\text { Classification } \\
\text { according to Graf }\end{array}$ & Left hip & Right hip & Total \\
\hline Ia & $253(56.2)$ & $254(56.4)$ & $507(56.3)$ \\
\hline Ib & $146(32.4)$ & $127(28.2)$ & $273(30.3)$ \\
\hline IIa+ & $39(8.7)$ & $53(11.8)$ & $92(10.2)$ \\
\hline IID & $2(0.4)$ & $2(0.4)$ & $4(0.4)$ \\
\hline IIg(c) & $9(2.0)$ & $13(2.9)$ & $22(2.4)$ \\
\hline IIIa & $1(0.2)$ & $1(0.2)$ & $2(0.2)$ \\
\hline IV & 0 & 0 & 0 \\
\hline
\end{tabular}


Of the total number of 450 newborns examined at birth, $37(8.2 \%)$ had excessive hip abduction: 13 of them had DDH, and 24 of them did not have DDH. In overall sample, there were 89 newborns with one of the forms of DDH. 13 (12.7\%) had this clinical sign; while 24
(6.9\%) of 324 newborns without DDH had this clinical sign. Excessive hip abduction had a positive predictive value (PPV) of $35.1 \%$ and a negative predictive value (NPV) of $78.5 \%$ for DDH (Table 2).

Table 2. Prevalence of developmental hip dysplasia considering excessive hip abduction with the measures of diagnostic accuracy

\begin{tabular}{|l|c|c|c|}
\hline \multirow{2}{*}{} & \multicolumn{2}{|c|}{$\begin{array}{c}\text { No (\%) of newborns with developmental } \\
\text { displacement of the hip }\end{array}$} & \multirow{2}{*}{ Total } \\
\cline { 2 - 3 } & Without deformity & With deformity & \\
\hline Excessive abduction & $324(93.1)$ & $89(87.3)$ & $413(91.8)$ \\
\hline positive & $24(6.9)$ & $13(12.7)$ & $37(8.2)$ \\
\hline negative & $348(100)$ & $102(100)$ & $450(100)$ \\
\hline Total & & & \\
\hline
\end{tabular}

Sensitivity $=12.7 \%$; Specificity $=93.1 \%$; Positive predictive value $=35.1 \%$; Negative predictive value $=$ $78.5 \%$

Out of 10 newborns with this clinical sign, three of them will have one of the types of developmental hip dysplasia, and out of 10 newborns who do not have this clinical sign, eight will not have DDH. The univariate analysis has shown that excessive hip abduction in newborns has a significant correlation with the presence of DDH $(\mathrm{OR}=2.475$; CI95\% 1.115-5.493) $(\mathrm{p}=0.026)$.

\section{DISCUSSION}

Developmental dysplasia of the hip, as one of the most common malformations of the locomotor system, is a significant health issue (16). No other disorder gives such good results through treatment as developmental dysplasia of the hip if it is detected and treated on timely. Primary prevention for developmental dysplasia of the hip is impossible to conduct since the primary cause of this disorder is not known (1). Today, it is possible to conduct secondary prevention which is based on very early diagnosis achieved through screening $(7,17)$. It is of great importance to recognize the newborns at risk of DDH. If DDH is recognized early, treatment is less invasive, and long-term effects are minimized (10). Late detection causes increased treatment complexity and a sevenfold increase in the short-term costs of treatment, compared to early detection and successful management in a Pavlik harness (18).

This study has shown the significant predictive value of excessive hip abduction for DDH. The diagnostic accuracy of excessive hip abduction, taking into account the sensitivity, specificity and predictive value, is $74.89 \%$. Later cases of dysplasia, subluxation and luxation (in the second and third month after birth) are found within cases of undiagnosed primary contracture of the hip and within cases of malposition syndrome (plagiocephaly, torticollis, thoracic 'C' scoliosis, oblique Vaisman pelvis and foot deformities) which is another reason why a child should be examined in the sixth week of life (19). This study has shown that $35 \%$ of newborns with excessive hip abduction had one of the types of DDH. Some of the studies showed unreliability of the clinical examination in diagnosing DDH $(20,21)$. Excessive hip abduction is a time-dependent and useful clinical sign in the diagnosis of pathological DDH (22).

\section{CONCLUSION}

In conclusion, excessive hip abduction is an useful and important clinical sign of DDH. Doctors who perform the first examination of the child after birth would have to turn their attention to this clinical sign. The newborns with this clinical sign would have to go to an ultrasound examination of the hips for further diagnosis.

\section{REFERENCES}

1. Noordin S, Umer M, Hafeez K, Nawaz H. Developmental dysplasia of the hip. Orthop Rev (Pavia) 2010; 2:e19.

2. Grgurić J. Uloga pedijatra u provedbi ortopedske zaštite djeteta. Pediatr Croat 2001; 45:35-7.

3. Guille JT, Pizzutillo PD, MacEwen GD. Development dysplasia of the hip from birth to six months. J Am Acad Orthop Surg 2000; 8:232-42.

4. Karmazin BK, Gunderman RB, Coley BD, Blatt ER, Bulas D, Fordham L, Podberesky DJ, Prince JS, Paides C, Rodriguez W. ACR Appropriateness Criteria on developmental dysplasia of the hip-child. J Am Coll Radial 2009; 6:551-57.

5. Schwend RM, Shaw BA, Segal LS. Evaluation and treatment of developmental hip dysplasia in the newborn and infant. Pediatr Clin North Am 2014; 61:1095-107.

6. Drnasin K, Vrdoljak J, Fridl VV, Saraga M. Ultrazvučni probir za razvojni poremećaj zgloba kuka u primarnoj pedijatriskoj zdrastvenoj zaštiti Grafovom metodom. Pediatr Croat 2001; 45:57-60 
7. Kotlarsky P, Haber R, Bialik V, Eidelman M. Developmental dysplasia of the hip: What has changed in the last 20 years? World J Orthop 2015; 6:886-901.

8. Vrdoljak J. Razvojni poremećaj zgloba kuka i ultrazvučna dijagnostika. Pediatr Croat 2000; 44(supl 1):141-6.

9. Dezateux C, Rosendahl K. Developmental dysplasia of the hip. Lancet 2007; 369:1541-52.

10. Amanda CR, Thomas MJ, Klane KW. Musculoskeletal screening: developmental dysplasia of the hip. Pediatric Annals 2013;42:238-44.

11. Gavrankapetnović I. Razvojni poremećaj kuka. In: Gavrankapetanović I, editor. Osnovi dječije ortopedije. Sarajevo: IP "Svjetlost" Zavod za udžbenike i nastavna sredstva; 2001;15-32.

12. Srval A, Coscun B, Irem B, Cengiz T, Tugba C. Is clinical examination reliable in diagnosis of develompmental dysplasia of the hip? Gazitip Dergisis Med J 2008; 19:569.

13. Bache CE, Clegg J, Herron M. Risk factors for developmental dysplasia of the hip:ultrasonographic findings in the neonatal period. J Pediatr Orthop B2002; 11:212-18.

14. Roof AC, Jinguji TM, White KK. Musculosceletal screening developmental dysplasia of the hip. Pediatr Ann 2013; 42:229-35.
15. Graf R, Mohajer M, Plattner. Hip sonography update. Quality-menagement, catastrophes-tips and tricks. Med Ultrason 2013; 4:299-303.

16. Tian FD, Zhao DW, Wang W, Guo L, Tian SM, Fan A, Yang F, Li DY. Prevalence of developmental dysplasia of the hip in Chinese adults: a cross-sectional survey. Chin Med J 2017; 130:1261-68.

17. Vrdoljak J, Bralić I, Vrdoljak O, Čimić M, Vukelić V. Mogućnosti probira razvojnog poremećaja kuka. Paediatr Croat 2016; 60:221-25.

18. Woodacre T, Dhadwal A, Ball T, Edwards C, Cox PJ. The costs of late detection of developmentaldysplasia of the hip. J Child Orthop Aug 2014; 8:325-32.

19. Pajić M, Vukašinović Z, Seslija I, Zivković Z. Neonatal hip dysplasia-differential diagnosis. Srp Arh Celok Lek 2010; 138:609-13.

20. Čustović S, Pavić V, Šadić S, Bačić B. Pouzdanost kliničke dijagnostike razvojnog poremećaja kuka kod dojenčeta. Acta Med Sal 2006; 35:19-25.

21. Simić S, Vukašinović Z, Samardžić J, Pejčić I, LukavacTesini M. Does the Gestation of Newborn Babies Influence the Ultrasonic Assessment of Hip Condition? Srp Arh Celok Lek 2009; 137:402-8.

22. Paton RW.Screening in Developmental Dysplasia of the Hip (DDH). Surgeon 2017; 15:290-6. 